\title{
EFFECT OF BRIQUETTE COMPOSITION AND SIZE ON THE QUALITY OF THE RESULTING COKE
}

\author{
M.G. Montiano, E. Díaz-Faes, C. Barriocanal* \\ Instituto Nacional del Carbón (INCAR-CSIC), Apartado 73, 33080 Oviedo. Spain \\ ${ }^{*}$ Corresponding author. Phone:+34 9851189 58; Fax: +34 9852976 62; email: \\ carmenbr@incar.csic.es
}

\section{ABSTRACT}

Five briquettes were prepared using sawdust, a non-coking coal and a binder. Industrial coal blends were used to study the influence of the type of sawdust (pine and chestnut), the binder (coal tar and coal-tar sludge) and the size of the briquettes on the quality of the cokes produced from mixtures containing up to 15 wt. $\%$ of the five briquettes. The effect of the briquettes and briquette components on the fluidity of the industrial coal blends was investigated. It was found that biomass and non-coking coal produced a decrease in fluidity, whereas the binders increased it. The combined effect of both types of additive had the global effect of decreasing fluidity. Mixtures of the briquettes with the industrial coal blends were carbonized in a $17 \mathrm{~kg}$ movable wall oven in order to assess their influence on the quality of the cokes produced. Their cold mechanical strength (JIS DI150/15 index), reactivity to $\mathrm{CO}_{2}(\mathrm{CRI}$ index) and postreaction strength (CSR index) were also tested. The composition of the ash of the sawdusts and the reactivity of the briquette components were used as an indication of the effect on coke reactivity. The effects on cold mechanical strength and post-reaction strength were different in some cases.

Keywords: coke; biomass; briquettes; mechanical strength; reactivity 


\section{Introduction}

The steel industry is an energy and carbon-based intensive process and therefore a major contributor to global anthropogenic $\mathrm{CO}_{2}$ emissions [1-4]. At the same time, cokemaking is a process where the recycling of wastes is possible, especially high carbon and low ash wastes like sawdust and charcoal [5-9], plastics [10-12], and bituminous wastes [13-15]. Thus recycling in the cokemaking industry could provide a way to reduce the environmental impact of $\mathrm{CO}_{2}$ emissions, reduce costs and widen the raw materials spectrum to include non-fossil fuels.

The inclusion of sawdust in coal blends for cokemaking has clear advantages such as its low sulphur and ash content and its zero contribution to $\mathrm{CO}_{2}$ emissions but it also has a number of disadvantages including its low char yield, deleterious effect on coal fluidity $[16,17]$ and low bulk density [18]. A possible way to increase the bulk density of the biomass is to prepare briquettes. Partial briquetting of coal charges was introduced by the Japanese industry in the 70 s, as this technique enabled the amount of expensive prime coking coal in the blend to be reduced and a cheap non-coking coal to be used instead without any deterioration of the quality of the resultant coke [19]. In a previous paper [7] a comparison of the direct addition of sawdust and addition via briquetting was carried out. However, other factors such as size and composition still need to be evaluated in order to know whether it is possible to apply sawdust briquetting to cokemaking.

Various binders can be used for the preparation of briquettes. However both sawdust and non-coking coal have a deleterious effect on the development of coal fluidity $[16,17]$ making pitch and coal tar preferable binders considering that both of these produce an increase in coal fluidity $[20,21]$. Coal-tar pitch has already been successfully used as a binder [22]. The role of pitch in briquettes comprising high-rank and coking coals is to interact with them and modify their carbonization behaviour so that the system is sufficiently fluid to wet the surface of non-fusing coals. In addition it 
needs to be able to form a binder coke with a mosaic optical texture that connects coalderived coke with inerts. The drawback with coal-tar pitch is its high carcinogenic compounds content [23]. An alternative option is to use coal tar which does not cause as great an increase in fluidity as coal tar pitch but is nevertheless a liquid and has fewer carcinogenic polyaromatics.

The aim of the present research work is to determine the influence of the type of sawdust and the size of the briquettes and binder used for their preparation on the quality of the coke produced from the co-carbonization of the briquettes with industrial coal blends.

\section{Experimental}

\subsection{Materials characterization}

Three industrial coal blends (CB2, CB3, CB4) were used together with the briquettes in the carbonization tests. The briquettes were prepared using a low volatile non-coking coal (C) and two sawdusts, one from chestnut (SC) and the other from pine (SP). As binder for the preparation of the briquettes coal tar $(\mathrm{T})$ and coal tar sludge $(\mathrm{M})$ from the coking plant were used. The raw gas evolving from the coke ovens is treated in order to separate the permanent gases, ammonia, benzol, and tar. The coal tar sludge (M) collected at the bottom part of the tar decanter, apart from tar also contains some coal and coke that is drawn away and deposited on the bottom of the decanter. Five briquettes with different compositions were prepared using a roll press briquetting machine (Table 1). The briquettes were ellipsoid shaped with axes 46 and $42 \mathrm{~mm}$ in length and weighting around $23 \mathrm{~g}$. On the basis of their different compositions it is possible to study: 1. the influence of including SC (B1 vs. B4 and BM1 vs. BM4); 2. the influence the type of binder (B4 vs. BM4 and B1 vs. BM1); 3. the effect of the two sawdusts, chestnut vs. pine (BM1 vs. BM1 $\left.1_{\mathrm{sp}}\right)$. To study the effect of the size, samples of briquette of weight between 4 and $6 \mathrm{~g}$, with the same composition as $\mathrm{BM} 1_{\mathrm{sp}}$ and BM4 were used for the co-carbonization tests and labelled BM1 $1_{\mathrm{SP}-\mathrm{F}}$ and $\mathrm{BM} 4_{\mathrm{F}}$ 
Elemental analysis was carried out following the standard ISO 562 and ISO 1171 procedures for humidity, ash and volatile matter respectively. For the elemental analysis the following standard procedures were used: ASTM D 5016-98 and ASTM D 5373-02 for $\mathrm{C}, \mathrm{H}$ and $\mathrm{N}$ using a LECO CHN-2000 and a LECO S-144 DR instrument for the analysis of S.

The apparent density of the briquettes was determined by means of water displacement by immersing 6 briquettes in a $500 \mathrm{ml}$ container. The density of briquettes $\mathrm{BM} 1_{\mathrm{SP}-\mathrm{F}}$ and $\mathrm{BM} 4_{\mathrm{F}}$ could not be measured because they disintegrate in water.

\subsection{Textural characterization}

The particle size used to determine the porous structure of the materials was between 1.18 and $0.8 \mathrm{~mm}$. The true density $\left(\rho_{\mathrm{He}}\right)$ of the sawdusts was measured by means of helium picnometry on a Micromeritics Accupyc 1330 Pycnometer. Their apparent density $\left(\rho_{\mathrm{Hg}}\right)$ was determined using mercury at $0.1 \mathrm{MPa}$ on a Micromeritics autopore IV 9500 mercury porosimeter. From the true and apparent densities the open porosity corresponding to pore sizes of less than $12 \mu \mathrm{m}$ was calculated by means of the following equation :

$$
\varepsilon(\%)=\left(1-\frac{\rho_{\mathrm{Hg}}}{\rho_{\mathrm{He}}}\right) \cdot 100
$$

The total pore volume $\left(\mathrm{V}_{\mathrm{T}}\right)$ was obtained from the equation:

$$
V_{T}\left(\mathrm{~cm}^{3} / \mathrm{g}\right)=\left(\frac{1}{\rho_{\mathrm{Hg}}\left(\mathrm{g} / \mathrm{cm}^{3}\right)}-\frac{1}{\rho_{\mathrm{He}}\left(\mathrm{g} / \mathrm{cm}^{3}\right)}\right)
$$


The pore size distribution was calculated by applying increasing pressure to the sample from 0.1 to $227 \mathrm{MPa}$. This resulted in pore sizes in a range of $12 \mu \mathrm{m}$ to $5.5 \mathrm{~nm}$ according to the Washburn equation.

Pore size was classified into two categories: macropores $(12 \mu \mathrm{m}>d p>50 \mathrm{~nm})$ and mesopores $(50 \mathrm{~nm}>\mathrm{dp}>5.5 \mathrm{~nm})$.

2.3. Variation of coal blend fluidity due to briquette addition

The thermoplastic properties of mixtures of the coal blends with 5,10 and 15 wt.\% of briquettes B1, BM1, BM1sp, B4 and BM4 were measured. Also the effect of the two binders, the sawdusts and the non-coking coal on the fluidity of the coal blends was assessed by means of the Gieseler test (ASTM D2639-74), this test having been successfully used previously to determine the modification of coal fluidity due to the use of additives $[17,20,24]$. The sample was heated at $3{ }^{\circ} \mathrm{C} / \mathrm{min}$ up to a final temperature of $550{ }^{\circ} \mathrm{C}$, while a constant torque was applied to the stirrer inside the crucible containing the sample. The spin rate of the stirrer was measured continuously until it stopped. The parameters derived from this test were: (i) softening temperature, Ts; (ii) the temperature of maximum fluidity, Tf; (iii) resolidification temperature, Tr; (iv) plastic range, Tr-Ts, which is defined as the difference between the resolidification and softening temperatures; and (v) maximum fluidity, MF, expressed as dial divisions per minute (ddpm).

\subsection{Thermogravimetric analysis (TG)}

Gasification was studied on a TA Instruments SDT 2960 thermobalance. Samples of weight 3-5 $\mathrm{mg}$ with a particle size of $<0.212 \mathrm{~mm}$ were heated in $\mathrm{N}_{2}$ up to $1100{ }^{\circ} \mathrm{C}$ and once the temperature was stabilized they were treated with $\mathrm{CO}_{2}$ using a flow of $100 \mathrm{ml} / \mathrm{min}$ until a conversion degree higher than $50 \%$ was reached. The cokes/chars employed for the gasification in the thermobalance were prepared in a horizontal oven using a heating rate of $5{ }^{\circ} \mathrm{C} / \mathrm{min}$. The carbon conversion $(\mathrm{x})$ and gasification rate or reactivity ( $r$ ) were calculated be means of the following equations: 


$$
\begin{aligned}
& x=\frac{m_{0}-m_{t}}{m_{0}-m_{\text {ash }}} \times 100 \\
& r=\frac{d x}{d t}
\end{aligned}
$$

where $m_{0}$ represents the initial mass of char and $m_{t}$, the mass at time $t$.

\subsection{Carbonization tests and coke quality determination}

Carbonization tests were carried out in a movable wall oven of approximately $17 \mathrm{~kg}$ capacity (MWO17) [25]. The dimensions of the oven are $250 \mathrm{~mm} \mathrm{~L} \mathrm{x} 165 \mathrm{~mm} \mathrm{~W} \times$ $790 \mathrm{~mm} \mathrm{H}$. The samples were charged when the oven had reached $1100{ }^{\circ} \mathrm{C}$. The temperature of the wall was kept constant throughout the test. The duration of the coking was approximately $3.5 \mathrm{~h}$. The industrial coal blends were carbonized with a bulk density of $782 \pm 5 \mathrm{~kg} / \mathrm{m}^{3}$

The cold mechanical strength of the cokes produced was assessed by the JIS test (JIS K2151 standard procedure). After the test the coke was sieved and the DI150/15 index was calculated from the amount of coke with a particle size greater than $15 \mathrm{~mm}$. Coke reactivity and mechanical strength after reaction were assessed by means of the NSC test (ASTM D5341 standard procedure) [26]. Two indices were derived from this test i.e. the CRI index which represents the loss of weight of a $200 \mathrm{~g}$ sample of coke with size between 19 and $22.4 \mathrm{~mm}$ after reaction with $\mathrm{CO}_{2}$ at $1100{ }^{\circ} \mathrm{C}$ for two hours and the CSR index which represents the percentage of partially reacted coke that remains on a $9.5 \mathrm{~mm}$ sieve after 600 revolutions in a standardized drum. The relationship between the CSR values obtained in a MWO of $17 \mathrm{~kg}$ capacity and those obtained in a MWO of $300 \mathrm{~kg}$ capacity has been reported previously [27].

3. Results and discussion 


\subsection{Characteristics of the material}

The three industrial coal blends used have similar characteristics (Table 2) sulphur and ash contents around 0.56 and 8.4 wt.\% respectively and a maximum Gieseler fluidity between 600 and $1000 \mathrm{ddpm}$. The highest oxygen and lowest carbon contents correspond to the sawdust.

It is well known that the bulk density of the charge has a strong influence on the quality of the coke, especially on the mechanical strength and strength after the reaction with $\mathrm{CO}_{2}$ (CSR index) [28]. In a previous research paper it was shown that the direct addition of sawdust to an industrial coal blend produced a decrease in the bulk density of the charge of $17 \mathrm{~kg} / \mathrm{m}^{3}$ while the addition of sawdust in the form of briquettes increased it by $11 \mathrm{~kg} / \mathrm{m}^{3}[7]$.

The apparent density of the briquettes is shown in Table 3 . The highest apparent density corresponds to B4 which was prepared using a non-coking coal and tar as binder. For briquettes prepared with the same binder those containing biomass have a lower density $\left(\rho \mathrm{B} 1<\rho \mathrm{B} 4\right.$ and $\left.\rho \mathrm{BM} 1_{\mathrm{SP}}<\rho \mathrm{BM} 4\right)$. The effect of $\mathrm{SC}$ with tar as binder (B1) compared to B4 is a reduction in density of $8 \%$, while in the case of briquettes prepared with coal tar sludge $(\mathrm{M})$ as binder and $\mathrm{SP}\left(\mathrm{BM} 1_{\mathrm{SP}}\right)$ compared to BM4, the reduction is around $24 \%$. The type of sawdust is also important, in the case of briquettes prepared with coal tar sludge and $\mathrm{SC}\left(\rho \mathrm{BM} 1=1179 \mathrm{~kg} / \mathrm{m}^{3}\right)$, while the density of the briquettes prepared with coal tar sludge and pine sawdust is lower $\left(\rho B M 1_{S P}=873 \mathrm{~kg} / \mathrm{m}^{3}\right)$. In order to explain these results two factors may play a role: the particle size distribution of the sawdusts and their porous structure. While SC has a 4 wt. $\%$ proportion of particles lower than $0.5 \mathrm{~mm}$, SP has $20 \mathrm{wt} . \%$ of this size [6]. The finer particle size distribution implies that there is a greater contact surface available for coverage by the binder. The structure of the two sawdusts was studied by SEM in order to find differences between soft and hardwood [29] that might corroborate differences in their ability to produce dense briquettes. Figure 1 shows images which clearly indicate that the porous structure in both types of sawdust is different. While SC 
has pores of two sizes (see Figure 1a and 1b) corresponding to vessels (greater than $100 \mu \mathrm{m}$ ) and traqueids (approx. 15-25 $\mu \mathrm{m}$ ) which are common in hardwood, SP (see Figure 1c and 1d) presents a more regular porous structure with only one size corresponding to small traqueids for the transport of fluids. In the case of SC the larger size of the pores will facilitate the wetting of particles and the agglomeration of the sawdust since the binder will penetrate more easily.

In order to confirm the different porous structures of the two sawdusts used i.e. SP (softwood) and SC (hardwood), the textural characteristics of both sawdusts have been assessed by means of $\mathrm{He}$ and $\mathrm{Hg}$ picnometry and $\mathrm{Hg}$ porosimetry. Table 4 displays the textural characteristics of the sawdusts. The total pore volume $\left(V_{\text {total }}\right)$ and porosity $(\epsilon)$ are higher in the case of SC but the most significant difference is to be found in their different macropore volumes $\left(\mathrm{V}_{\text {macro }}\right)$. The macropore volume of $\mathrm{SC}$ is more than double that of SP, facilitating the entrance of the binder to produce denser briquettes.

To study the effectiveness of the two binders, a comparison of the density of B4 with that of BM4 and of B1 with that of BM1 was carried out. The values in Table 3 indicate that BM4 has a density $19 \%$ lower than that of B4, while BM1 has a density which is only $10 \%$ lower than that of B1. The different effectiveness of the two binders may be related to the presence of inert materials in the case of $\mathrm{M}[30] . \mathrm{BM} 1_{\mathrm{SP}}$ has the lowest density (38\% lower than B4) because it combines the lesser effectiveness of the tar decanter sludge (M) as binder and the presence of SP which produces briquettes with a lower density.

\subsection{Modification of coal thermoplastic properties}

As a first step for studying the modification by the briquettes of coal fluidity, the effect of the briquette components was tested. Figure $2 a$ and $2 b$ show the effect of increasing amounts of binder, biomass and non-coking coal respectively. Both binders produce an increase in fluidity but it is greater in the case of the tar, probably due to the 
amount of inerts present in the tar decanter sludge. Such bituminous additives favor coal fluidity because they provide molecular species that have the effect of plasticizing the entire system. On the other hand sawdust and non-coking coal cause a decrease in fluidity (Figure 2b). It can be seen that an addition of 2 wt. $\%$ of sawdust produces a reduction of between $40-45 \%$ in the fluidity of the coal blend, which is slightly higher in the case of pine sawdust. The drastic reduction in coal fluidity due to biomass has already been reported in the case of individual coals and blends $[6,16,17]$. The reduction observed when adding to a high volatile and highly fluid coal was slightly greater [16] than for the coal blends [6]. The effect is lower for coal blends probably due to a compensatory effect coming from the number of coals of different rank and origin. Clearly more work is needed in order to determine the effect of sawdust as a function of coal rank and in coal blends.

Figure $2 \mathrm{~b}$ shows that the non-coking coal $(\mathrm{C})$ produced a reduction in fluidity but to a lower extent than the two sawdusts. Fitting the points corresponding to each additive in Figure $2 \mathrm{~b}$ produces lines with slopes of $-17.8,-16.2$ and -3.4 for SP, SC and the non-coking coal respectively.

The composition of the briquettes includes a binder that increases fluidity but also inerts that produces a decrease in fluidity. In order to confirm the combined effect, mixtures of the coal blend with increasing amounts of the briquette were prepared and their fluidity tested, as shown in Figure 3. All the briquettes tested produced a reduction in the fluidity of the coal blends. The deleterious effect in decreasing order was as follows: $\mathrm{B} 4<\mathrm{BM} 4<\mathrm{BM} 1 \mathrm{sp}<\mathrm{B} 1<\mathrm{BM} 1$. According to the results in Figure 2, the briquettes with no sawdust produce the least deleterious effect followed by those with sawdust. Although the binders increase fluidity they are not able to compensate for the decrease in fluidity caused by the non-coking coal and the sawdust. The fluidity of the mixture was in all cases greater than $300 \mathrm{ddpm}$ which is inside the range required for a coking coal i.e. between 200 and 1000 ddpm. 


\subsection{Modification of coke quality due to briquette addition}

The cokemaking industry uses standardized methods to evaluate the quality of the cokes produced. In the case of mechanical strength the tests usually provide two indices, one of which represents the cohesiveness of the material and the other resistance to abrasion. It is usually the case that the higher the cohesiveness is, the lower the resistance to abrasion. Another quality parameter normally measured is its reactivity to $\mathrm{CO}_{2}$ and its mechanical strength after reaction which is shown by means of the CRI/CSR indices. These two parameters give an indication of the behavior of a coke in the blast furnace. The raw materials used to prepare the briquettes have a different origin, composition, structure etc. which will affect the coke properties (i.e. the CRI and CSR indices will be different). To clarify the effect on coke reactivity, the briquette components were gasified in $\mathrm{CO}_{2}$ at $1100{ }^{\circ} \mathrm{C}$. This temperature was chosen because it is the temperature used to determine the CRI index used in the cokemaking industry to characterize coke quality. Figure 4 shows the variation of conversion $(x)$ and reactivity ( $r$ ) expressed as the derivative of the conversion with time for all the briquette components. From the TG/DTG data the following parameters were derived (see Table 5): time and reactivity for a conversion of $50 \%\left(t_{x=50 \%}\right.$ and $r_{x=50 \%)}$, time for maximum reactivity $\left(\mathrm{t}_{\mathrm{rmax}}\right)$, maximum reactivity $\left(\mathrm{r}_{\max }\right)$ and conversion at maximum reactivity $\left(\mathrm{x}_{\mathrm{rmax}}\right)$. The two sawdusts required the least time to achieve a conversion of $50 \%$, around 4 min while in the case of the rest of the materials more than 8 min was needed. In addition the maximum gasification rate was more than three times that of the other materials (Table 5). The high reactivity of the biomass chars is due to the presence of $\mathrm{K}$ and $\mathrm{Ca}$ salts which catalyze the gasification reaction [31]. In the present research work the composition of the ashes from the two sawdusts was studied and the results are presented in Table 6 . The basicity index has been calculated taking into account the ash content and the ratio of basic to acidic oxides [32]. This index is higher in the case of SC due to the higher ash content but if the ash content is ignored the ratio of 
basic to acidic oxides is very similar for both sawdusts (1.49 for SC and 1.57 for SP). The sawdust from pine has a very low ash content $(0.3 \mathrm{wt} . \% \mathrm{db})$ but the $\mathrm{K}$ content of the ashes is much higher than in SC (14 vs. 4 wt.\%) and some authors have linked the $\mathrm{K}$ content to the catalytic effect of the biomass ashes [33]. The two sawdusts have the highest reactivity followed by the non-coking coal and the coal tar sludge and the tar. This reactivity order may serve as an indicator of the modification of the reactivity of the cokes prepared with the briquettes.

The variation of the coke quality indices is expressed as the difference between the value obtained for the coke produced from the industrial coal blend and that corresponding to the coke prepared from the mixture of the coal blend and the briquette. The quality of the cokes produced from the base blends is presented in Table 7. As can be observed, the CSR value which is the parameter generally accepted by cokemaking industry to evaluate coke quality is the same for all three base blends. Figure 5 shows the variation of the mechanical strength index (DI150/15) and the CRI and CSR indices with the amount of briquettes B1, B4, BM1 and BM4. In the graphs the difference in the quality index corresponding to the base blend and that corresponding to its mixtures with briquettes is expressed as $\Delta \mathrm{JIS} \mathrm{D} 150 / 15, \Delta \mathrm{CRI}$ and $\Delta \mathrm{CSR}$. It is possible by means of this comparison to evaluate the effect of including sawdust (B1 vs. B4 and BM1 vs. BM4) and the effect of the type of binder (B1 vs BM1 and B4 vs.

BM4). The addition of these four types of briquettes produces a decrease in the JIS index. The lowest values correspond to the briquettes that contain sawdust. In the case of $15 \mathrm{wt} . \%$ addition the results are very similar both with and without biomass (BM1 and BM4 respectively) when coal tar sludge (M) is used as binder. It appears that, when sawdust is used, the presence of filler material in the binder has a beneficial effect on the integration of the biomass within the briquette and as a result in the coke 
matrix, by reducing the risk of fissures or weak points where rupture is likely to occur. When sawdust is included, $M$ is better than $T$ as binder.

The addition of briquettes with no sawdust (B4 and BM4) does not produce any significant variation of the CRI index (less than 2 points for $15 \mathrm{wt} \%$ addition). On the other hand the inclusion of biomass in the briquettes causes an increase in the CRI index, especially when coal tar sludge is used as binder $(\Delta \mathrm{CRI}=8$ for $15 \mathrm{wt} \% \mathrm{BM} 1)$. In this case the binder makes a difference and coal tar produces briquettes that result in a lower increase in coke reactivity. As is well-known, the CRI and CSR indices are linearly related and low CRI values are associated to high CSR values $[26,28]$. The addition of briquettes with no sawdust produces cokes with similar CSR values as those of the base blend. The worst results were obtained for briquette BM1 with 15 wt. $\%$ addition: $\Delta \mathrm{CSR}=-14$. These poor results may be due to the lower density of the briquettes that include sawdust, as can be seen in Table 3. In order to explain the differences observed between using tar $(T)$ or coal tar sludge $(M)$ as binder, mixtures of the coal blend CB4 with direct addition of $\mathrm{T}$ and $\mathrm{M}$ were carried out. The results corresponding to the quality of the cokes produced are presented in the Supplementary Information (Figure 1S). The addition of both binders produced cokes with a lower mechanical strength than that of the base blend. The greatest difference in the D150/15 index was observed for the addition of $2.25 \mathrm{wt} . \%$ of binder corresponding to a 15 wt.\% briquette content in the charge, with $M$ producing a coke with a better mechanical strength than $\mathrm{T}$. This might explain why the mechanical strength of the coke obtained in the case of 15 wt. $\%$ addition of $B 1$ and BM1 was higher when $M$ was used than with $\mathrm{T}$ (Figure 5). In the case of the high temperature properties of the cokes (CRI and CSR indices), T produced cokes with slightly better characteristics than $\mathrm{M}$ $(\triangle \mathrm{CRI}=2$ and $\Delta \mathrm{CSR}=2)$ up to $1.5 \mathrm{wt} . \%$ addition which corresponds to a briquette addition of $10 \mathrm{wt} . \%$. The impairment of coke quality observed in the case $15 \mathrm{wt} . \%$ addition of BM1 can be attributed to the effect of the sawdust. 
The effect of the two types of sawdust in the preparation of the briquettes was also studied by adding briquettes $\mathrm{BM} 1$ and $\mathrm{BM} 1_{\mathrm{sp}}$. Figure 6 displays the variation in the coke quality indices with additions of these two briquettes up to $15 \mathrm{wt} . \%$. It can be seen (Figure 6) that cold mechanical strength decreases with the addition of both types of briquettes. The greatest difference was observed for $15 \mathrm{wt} \%$ addition which in the case of briquettes prepared with SP implies a difference in the JIS index of 7 points, while for briquettes with SC the drop is 5 . This is explained by the fact that the particle size distribution is finer in SP (20 wt.\% vs. 4 wt. $\%$ of $<0.5 \mathrm{~mm}$ ). The surface area of contact in SP is also greater, increasing the possibility of fissure and crack formation at the interface between the sawdust and the coal with a consequent decrease in mechanical strength [34]. In addition the density of the briquettes prepared with SP is lower than that of the briquettes prepared with SC. The CRI indices of the cokes produced increase with the amount of briquettes in the coking blend. Only slight differences were observed between the two sawdusts. The addition of the briquettes with SC produces a slightly more reactive coke than that with SP. This could be related to the higher reactivity of the SC char observed in the thermobalance and its higher basicity index. As a consequence of the increase in the CRI index due to the addition of briquettes the CSR diminishes.

The effect of the size of the briquettes on the quality of the cokes produced was tested by adding BM4 and comparing it to $\mathrm{BM} 4_{\mathrm{F}}$ and by adding $\mathrm{BM} 1_{\mathrm{SP}}$ and comparing it to $\mathrm{BM} 1_{\mathrm{SP}-\mathrm{F}}$. The coke quality indices are presented in Figure 7 . In general the decrease in the JIS index up to $15 \mathrm{wt} . \%$ is lower than 5 points except in the case of $\mathrm{BM} 1_{\mathrm{SP}}$ where the decrease is 7 points. The incorporation of smaller pieces of briquette led a lower diminution of cold mechanical strength. In general size is important when using additives as it determines the incorporation of the inerts into coke matrix, small inerts being more easily incorporated than large inerts. In the case of coke reactivity to $\mathrm{CO}_{2}$ the smaller briquettes produced a greater increase in the CRI index than the larger 
ones. This is in agreement with results reported in the literature that relate the size of the biomass to the reactivity of the coke produced from its blend with coal [35]. As a consequence of the high CRI the mechanical strength after reaction (CSR index) is low compared to the base blend (13-15 points for a $15 \mathrm{wt} . \%$ addition of $\mathrm{BM} 1_{\mathrm{SP}-\mathrm{F}}$ and $\mathrm{BM} 4_{\mathrm{F}}$ respectively). Although the charge characteristics are very important for coke quality, coking conditions also play an important role. In the present work the low bulk density values due to the low density of briquettes $\mathrm{BM} 1$ and $\mathrm{BM} 1_{\mathrm{SP}}$ led to the cokes with the lowest CSR values.

\section{Conclusions}

The addition of briquettes caused a decrease in the fluidity of the industrial coal blends irrespective of the amount added. However coke was produced by every mixture. The incorporation of briquettes containing sawdust, regardless of their origin impaired the cold mechanical strength, coke reactivity and post-reaction strength. Nevertheless slight differences between the two sawdusts were apparent at $15 \mathrm{wt} \%$ addition. The JIS index values improved in the case of BM1 due to the lower density of the $\mathrm{BM} 1_{\mathrm{SP}}$ briquettes while CRI and consequently CSR improved with the addition of briquettes containing pine sawdust $\left(\mathrm{BM} 1_{\mathrm{SP}}\right)$ due to the amount and composition of the ashes. Coal tar sludge was only better than tar as binder when briquettes with sawdust were added and as regards cold mechanical strength (JIS index). Additions of up to $10 \mathrm{wt} \%$ of briquettes containing biomass prepared with tar as binder yielded good results because the variation in the CSR was lower than 2 points. The inclusion of briquette fines produced cokes with lower CSR than when full size briquettes were used. When evaluating the effect of biomass containing briquettes the environmental benefits should be also considered.

\section{Acknowledgements}


The research leading to these results has received funding from the European Union's Research Programme of the Research Fund for Coal and Steel (RFCS) research programme under grant agreements No. [RFCR-CT-2010-00007 and RFCR-CT-201400006]. M.G.M. thanks the Government of the Principado de Asturias for the award of a pre-doctoral grant with funds from the PCTI-Asturias within the Severo Ochoa program.

References

[1] T. Ariyama, R. Murai, J. Ishii, M. Sato, Reduction of $\mathrm{CO}_{2}$ emissions from integrated steel works and its subjects for a future study, ISIJ Int 45 (2005) 1371-1378.

[2] C.M. Wiklund, F. Pettersson, H. Saxen, Optimal resource allocation in integrated steelmaking with biomass as auxiliary reductant in the blast furnace, ISIJ Int 52 (2012) 35-44.

[3] T. Norgate, N. Haque, M. Somerville, S. Jahanshahi, Biomass as a source of renewable carbon for iron and steelmaking, ISIJ Int 52 (2012) 1472-1481.

[4] A. Carpenter, $\mathrm{CO}_{2}$ abatement in the iron and steel industry, IEA Clean Coal Centre (2012).

[5] A. Hasanbeigi, M. Arens, L. Price, Alternative emerging ironmaking technologies for energy-efficiency and carbon dioxide emissions reduction: A technical review, Renew Sust Energ Rev 33 (2014) 645-658.

[6] M.G. Montiano, E. Díaz-Faes, C. Barriocanal, R. Álvarez, Influence of biomass on metallurgical coke quality, Fuel 116 (2014) 175-182.

[7] M.G. Montiano, E. Díaz-Faes, C. Barriocanal, Partial briquetting vs direct addition of biomass in coking blends, Fuel 137 (2014) 313-320.

[8] H. Suopajarvi, E. Pongracz, T. Fabritius, The potential of using biomass-based reducing agents in the blast furnace: A review of thermochemical conversion technologies and assessments related to sustainability, Renew Sust Energ Rev 25 (2013) 511-528.

[9] K.W. Ng, J.A. MacPhee, L. Giroux , T. Todoschuk, Reactivity of bio-coke with $\mathrm{CO}_{2}$, Fuel Process Technol 92 (2011) 801-804. 
[10] S. Melendi, M.A. Díez, R. Álvarez, C. Barriocanal, Plastic wastes, lube oils and carbochemical products as secondary feedstocks for blast-furnace coke production, Fuel Process Technol 92 (2011) 471-478.

[11] M.A. Diez, R. Álvarez, S. Melendi, C. Barriocanal, Feedstock recycling of plastic wastes/oil mixtures in cokemaking, Fuel 88 (2009) 1937-1944.

[12] S. Nomura, K.M. Thomas, Fundamental aspects of coal structural changes in the thermoplastic phase, Fuel 77 (1998) 829-836.

[13] G. Collin, B. Bujnowska, Co-carbonization of pitches with coal mixtures for the production of metallurgical cokes, Carbon 32 (1994) 547-552.

[14] K. Lundkvist, M. Larsson, C. Samuelsson, Optimisation of a centralised recycling system for steel plant by-products, a logistics perspective, Resour Conserv Recy 77 (2013) 29-36.

[15] U. Świetlik, G. Gryglewicz, H. Machnikowska, J. Machnikowski, C. Barriocanal, R. Álvarez, M.A. Diez, Modification of coking behaviour of coal blends by plasticizing additives, J Anal Appl Pyrol 52 (1999) 15-31.

[16] M.G. Montiano, C. Barriocanal, R. Álvarez, Effect of the addition of waste sawdust on thermoplastic properties of a coal, Fuel 106 (2013) 537-543.

[17] S. Kokonya, M. Castro-Díaz, C. Barriocanal, C.E. Snape, An investigation into the effect of fast heating on fluidity development and coke quality for blends of coal and biomass, Biomass Bioenerg 56 (2013) 295-306.

[18] M.G. Montiano, E. Díaz-Faes, C. Barriocanal, R. Álvarez, Influence of biomass on metallurgical coke quality, Fuel 116 (2014) 175-182.

[19] Y. Masakazu, S. Mitsugu, O. Toshiaki, U. Mataichi, Y. Hideki, Present status of production procedure for briquette blend coke, Nippon Steel Technical Report 10 (1977) 27-35.

[20] A.M. Fernández, C. Barriocanal, M.A. Díez, R. Álvarez, Influence of additives of various origins on thermoplastic properties of coal, Fuel 88 (2009) 2365-2372.

[21] A.M. Fernández, C. Barriocanal, M.A. Díez, R. Álvarez, Evaluation of bituminous wastes as coal fluidity enhancers, Fuel 101 (2012) 45-52.

[22] R. Álvarez, R. Menéndez, H. Marsh, E. A. Miyar, C.S. Canga, Improving coke strength by co-carbonization of aluminium with high volatile Spanish coal, Fuel 68 (1989) 1325-1329.

[23] A. Domínguez, R. Alvarez, C.G. Blanco, M.A. Díez, Chromatographic evaluation of some selected polycyclic aromatic hydrocarbons of coal tars produced under different coking conditions and pitches derived from them,J Chromatogr A 719 (1996) 181-194P. 
[24] C. Barriocanal, J.W. Patrick, A. Walker, The laboratory identification of dangerously coking coals, Fuel 77 (1998) 881-884.

[25] A.M. Fernández, C. Barriocanal, R. Álvarez, The effect of additives on coking pressure and coke quality, Fuel 95 (2012) 642-647.

[26] R. Álvarez, M.A. Díez, C. Barriocanal, E. Díaz-Faes, J.L.G. Cimadevilla, An approach to blast furnace coke quality prediction, Fuel 86 (2007) 2159-2166.

[27] E. Díaz-Faes, R. Álvarez, C. Barriocanal, M.A. Díez, Semi-pilot scale carbonization to assess blast furnace coke quality, ICCS\&T 2011 Proceedings P.1.20.

[28] R. Loison, P. Foch, A. Boyer, Coke quality and production, second ed., Butterworths, London (1989).

[29] B.G. Diehl, N.R. Brown, C.W. Frantz, M.R. Lumadue, F. Cannon, Effects of pyrolysis temperature on the chemical composition of refined softwood and hardwood lignins, Carbon, 60 (2013) 531-537.

[30] R. Álvarez, C. Barriocanal, M.A. Díez, J.L.G. Cimadevilla, M.D. Casal, C.S. Canga, Recycling of hazardous waste materials in the coking process, Environ Sci and Technol 38 (2004) 1611-1615.

[31] L. Ding, Y. Zhang, Z. Wang, J. Huang, Y. Fang, Interaction and its induced inhibiting or synergistic effects during co-gasification of coal char and biomass char, Bioresource Technol 173 (2014) 11-20.

[32] M.A. Díez, R. Álvarez, C. Barriocanal, Coal for metallurgical coke production: predictions of coke quality and future requirements for cokemaking, Int $\mathrm{J}$ Coal Geol 50 (2002) 389-412.

[33] R. Habibi, J. Kopyscinski, M.S. Masnadi, J. Lam, J.R. Grace, C.A. Mims, J.M. Hill, Co-gasification of biomass and non-biomass feedstocks: synergistic and inhibition effects of switchgrass mixed with sub-bituminous coal and fluid coke during $\mathrm{CO}_{2}$ gasification. Energ Fuels 27 (2012) 494-500.

[34] T. Matsumura, M. Ichida, T. Nagasaka, K. Kato, Carbonization behaviour of woody biomass and resulting metallurgical coke properties, ISIJ Int 48 (2008) 572-577.

[35] J.A. MacPhee, J.F. Gransden, L. Giroux, J.T. Price, Possible $\mathrm{CO}_{2}$ mitigation via addition of charcoal to coking coal blends, Fuel Process Technol 90 (2009) 16-20. 
Table 1. Briquettes composition

\begin{tabular}{c|ccccc} 
& B1 & B4 & BM1 & BM4 & BM1 \\
\hline $\mathrm{T}$ & 15 & 15 & - & - & - \\
$\mathrm{M}$ & - & - & 15 & 15 & 15 \\
$\mathrm{SC}$ & 15 & - & 15 & - & - \\
$\mathrm{SP}$ & - & & - & - & 15 \\
$\mathrm{C}$ & 70 & 85 & 70 & 85 & 70 \\
\hline
\end{tabular}


Table 2. Main characteristics of the raw materials

\begin{tabular}{|c|c|c|c|c|c|c|c|c|}
\hline & CB2 & CB3 & CB4 & $\mathrm{C}$ & SC & SP & $\mathrm{T}$ & M \\
\hline Ash $(\% d b)^{b}$ & 8.8 & 8.5 & 7.8 & 10.2 & 1.3 & 0.3 & $0.8^{\mathrm{a}}$ & $2.2^{a}$ \\
\hline Volatile Matter (\% db) & 23.9 & 23.0 & 26.2 & 14.5 & 78.5 & 85.3 & -- & -- \\
\hline Gieseler MF ${ }^{\mathrm{c}}$ (ddpm) & 682 & -- & 1016 & $\mathrm{n} / \mathrm{a}$ & $\mathrm{n} / \mathrm{a}$ & $\mathrm{n} / \mathrm{a}$ & $\mathrm{n} / \mathrm{a}$ & $\mathrm{n} / \mathrm{a}$ \\
\hline$C(\% \mathrm{db})$ & 80.3 & 82.1 & 82.4 & 80.8 & 50.2 & 50.7 & 90.3 & 89.1 \\
\hline $\mathrm{H}(\% \mathrm{db})$ & 4.6 & 4.7 & 4.9 & 4.0 & 5.7 & 6.1 & 4.7 & 4.2 \\
\hline$N(\% d b)$ & 1.8 & 1.9 & 1.9 & 1.7 & 0.5 & 0.5 & 0.8 & 1.1 \\
\hline$S(\% d b)$ & 0.58 & 0.51 & 0.62 & 0.45 & 0.01 & 0.00 & 0.38 & 0.52 \\
\hline$O(\% d b)^{c}$ & 3.9 & 2.1 & 2.4 & 2.9 & 42.3 & 42.4 & 3.0 & 5.1 \\
\hline \multicolumn{9}{|l|}{ Particle size (wt.\%) } \\
\hline$>3 \mathrm{~mm}$ & 12.0 & 20.4 & 26.6 & 14.9 & 1.0 & 0.2 & $\mathrm{n} / \mathrm{a}$ & $\mathrm{n} / \mathrm{a}$ \\
\hline 2-3 mm & 7.0 & 9.8 & 10.6 & 7.7 & 4.5 & 1.3 & $\mathrm{n} / \mathrm{a}$ & $\mathrm{n} / \mathrm{a}$ \\
\hline $1-2 \mathrm{~mm}$ & 14.8 & 16.6 & 17.0 & 15.3 & 24.6 & 19.8 & $\mathrm{n} / \mathrm{a}$ & $\mathrm{n} / \mathrm{a}$ \\
\hline $0.5-1 \mathrm{~mm}$ & 14.8 & 16.6 & 15.3 & 19.4 & 65.8 & 59.6 & $\mathrm{n} / \mathrm{a}$ & $\mathrm{n} / \mathrm{a}$ \\
\hline$<0.5 \mathrm{~mm}$ & 51.4 & 36.6 & 30.5 & 42.7 & 4.1 & 19.1 & $\mathrm{n} / \mathrm{a}$ & $\mathrm{n} / \mathrm{a}$ \\
\hline
\end{tabular}

There is a discontinuity in the text in line 334.pag 5 
Table 3. Apparent density of the briquettes

\begin{tabular}{c|ccccc} 
& B1 & BM1 & BM1 & BP & BM4 \\
\hline$\rho_{\mathrm{H} 2 \mathrm{O}}\left(\mathrm{kg} / \mathrm{m}^{3}\right)$ & 1312 & 1179 & 873 & 1415 & 1149
\end{tabular}


Table 4. Textural characteristics of the sawdusts.

\begin{tabular}{lcccccc}
\hline & $\begin{array}{c}\rho_{\mathrm{Hg}} \\
\left(\mathrm{g} / \mathrm{cm}^{3}\right)\end{array}$ & $\begin{array}{c}\rho_{\mathrm{He}} \\
\left(\mathrm{g} / \mathrm{cm}^{3}\right)\end{array}$ & $\begin{array}{c}\mathrm{V}_{\text {total }} \\
\left(\mathrm{cm}^{3}\right)\end{array}$ & $\begin{array}{c}\epsilon \\
(\%)\end{array}$ & $\begin{array}{l}\mathrm{V}_{\text {macro }} \\
\left(\mathrm{cm}^{3}\right)\end{array}$ & $\begin{array}{c}\mathrm{V}_{\text {meso }} \\
\left(\mathrm{cm}^{3}\right)\end{array}$ \\
\hline SC & 0.642 & 1.378 & 0.830 & 53.3 & 0.778 & 0.052 \\
SP & 0.688 & 1.407 & 0.742 & 51.1 & 0.271 & 0.010 \\
\hline
\end{tabular}

$\rho_{\mathrm{Hg}}$ : Apparent density. $\rho_{\mathrm{He}}$ : True density. $\mathrm{V}_{\text {total }}$ : Total pore volume. $\mathrm{V}_{\text {macro }}$ : Macropore volume. $\mathrm{V}_{\text {meso }}$ : Mesopore volume. 
Table 5. Parameters derived from the gasification tests in thermobalance.

\begin{tabular}{cccccc}
\hline & $\begin{array}{c}\mathrm{t}_{\mathrm{x}=50 \%} \\
(\min )\end{array}$ & $\begin{array}{c}\mathrm{r}_{\mathrm{x}=50 \%} \\
(\% / \mathrm{min})\end{array}$ & $\begin{array}{c}\mathrm{t}_{\mathrm{r} \max } \\
(\mathrm{min})\end{array}$ & $\begin{array}{c}\mathrm{r}_{\max } \\
(\% / \min )\end{array}$ & $\begin{array}{c}\mathrm{x}_{\mathrm{r} \max } \\
(\%)\end{array}$ \\
\hline $\mathrm{C}$ & 8.5 & 5.2 & 4.0 & 8.1 & 19.3 \\
$\mathrm{SC}$ & 4.1 & 25.9 & 5.1 & 28.5 & 78.1 \\
$\mathrm{SP}$ & 4.1 & 25.3 & 4.7 & 26.5 & 66.3 \\
$\mathrm{~T}$ & 36.7 & 1.3 & 16.0 & 1.6 & 18.7 \\
$\mathrm{M}$ & 15.7 & 2.8 & 6.7 & 4.4 & 16.8 \\
\hline
\end{tabular}


Table 6. Ash composition of the two sawdusts.

\begin{tabular}{l|cccccccccc} 
& $\begin{array}{c}\mathrm{SiO}_{2} \\
\text { (wt.\%) }\end{array}$ & $\begin{array}{c}\mathrm{Al}_{2} \mathrm{O}_{3} \\
(\text { wt.\%) }\end{array}$ & $\begin{array}{c}\mathrm{Fe}_{2} \mathrm{O}_{3} \\
(\text { wt.\%) }\end{array}$ & $\begin{array}{c}\mathrm{MgO} \\
\text { (wt.\%) }\end{array}$ & $\begin{array}{c}\mathrm{CaO} \\
(\text { wt. \%) }\end{array}$ & $\begin{array}{c}\mathrm{Na}_{2} \mathrm{O} \\
\text { (wt.\%) }\end{array}$ & $\begin{array}{c}\mathrm{K}_{2} \mathrm{O} \\
\text { (wt.\%) }\end{array}$ & $\begin{array}{c}\mathrm{TiO}_{2} \\
\text { (wt.\%) }\end{array}$ & $\begin{array}{c}\mathrm{P}_{2} \mathrm{O}_{5} \\
\text { (wt.\%) }\end{array}$ & $\mathrm{BI}^{*}$ \\
\hline $\mathrm{SC}$ & 28.38 & 7.10 & 3.18 & 3.79 & 41.21 & 0.60 & 4.09 & 0.29 & 1.72 & 1.93 \\
$\mathrm{SP}$ & 27.51 & 4.67 & 1.33 & 10.71 & 23.08 & 1.38 & 14.00 & 0.11 & 2.52 & 0.47 \\
\hline
\end{tabular}

${ }^{*} \mathrm{BI}=\mathrm{Ash} \cdot \frac{\left(\mathrm{Fe}_{2} \mathrm{O}_{3}+\mathrm{MgO}+\mathrm{CaO}+\mathrm{Na}_{2} \mathrm{O}+\mathrm{K}_{2} \mathrm{O}\right)}{\left(\mathrm{SiO}_{2}+\mathrm{Al}_{2} \mathrm{O}_{3}\right)}$ 
Table 7. Coke quality of the base blends.

\begin{tabular}{lccc}
\hline & JIS D150/15 & CRI & CSR \\
\hline CB2 & 75 & 26 & 60 \\
CB3 & 73 & 28 & 60 \\
CB4 & 79 & 26 & 60 \\
\hline
\end{tabular}




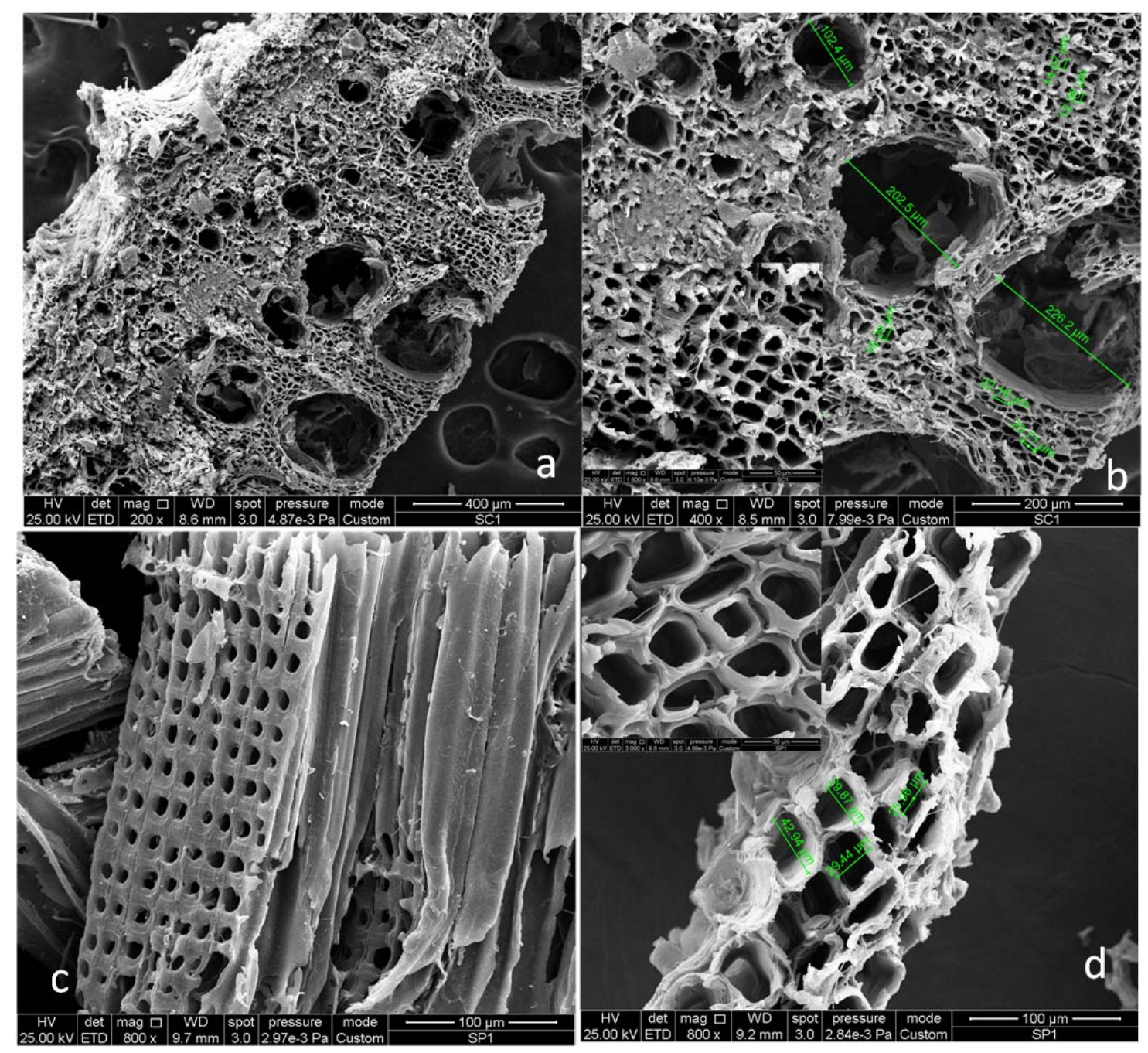

Figure 1. SEM images of sawdust showing different structure of chestnut and sawdust. SC (a and b), SP (c and d). 

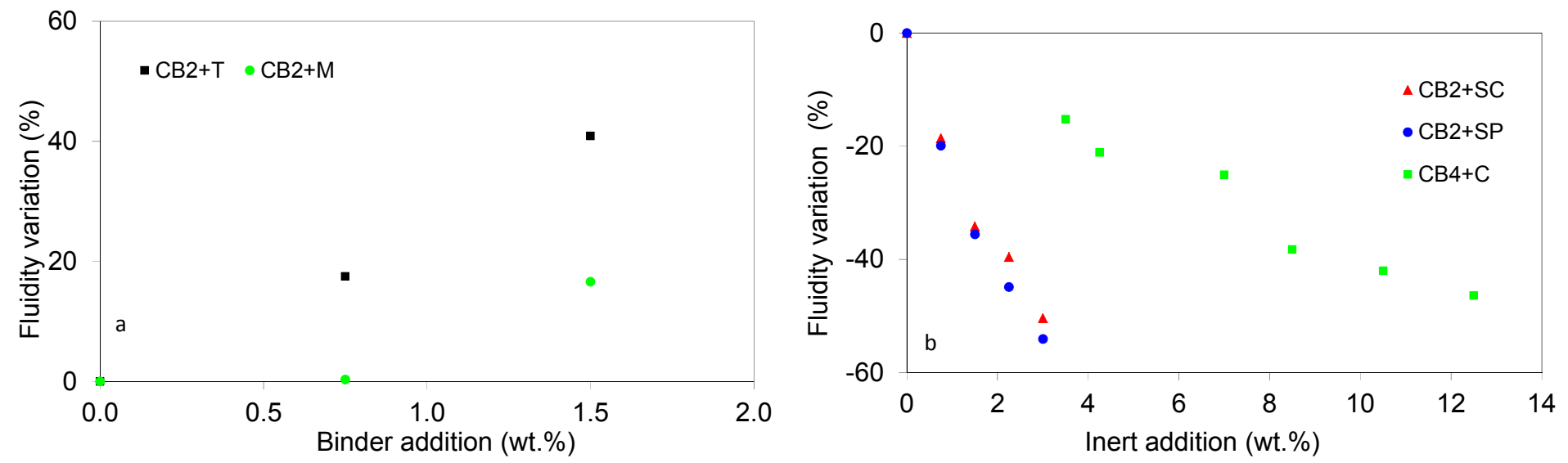

Figure 2. Variation of maximum fluidity of coal blends with the addition of the briquette components. 


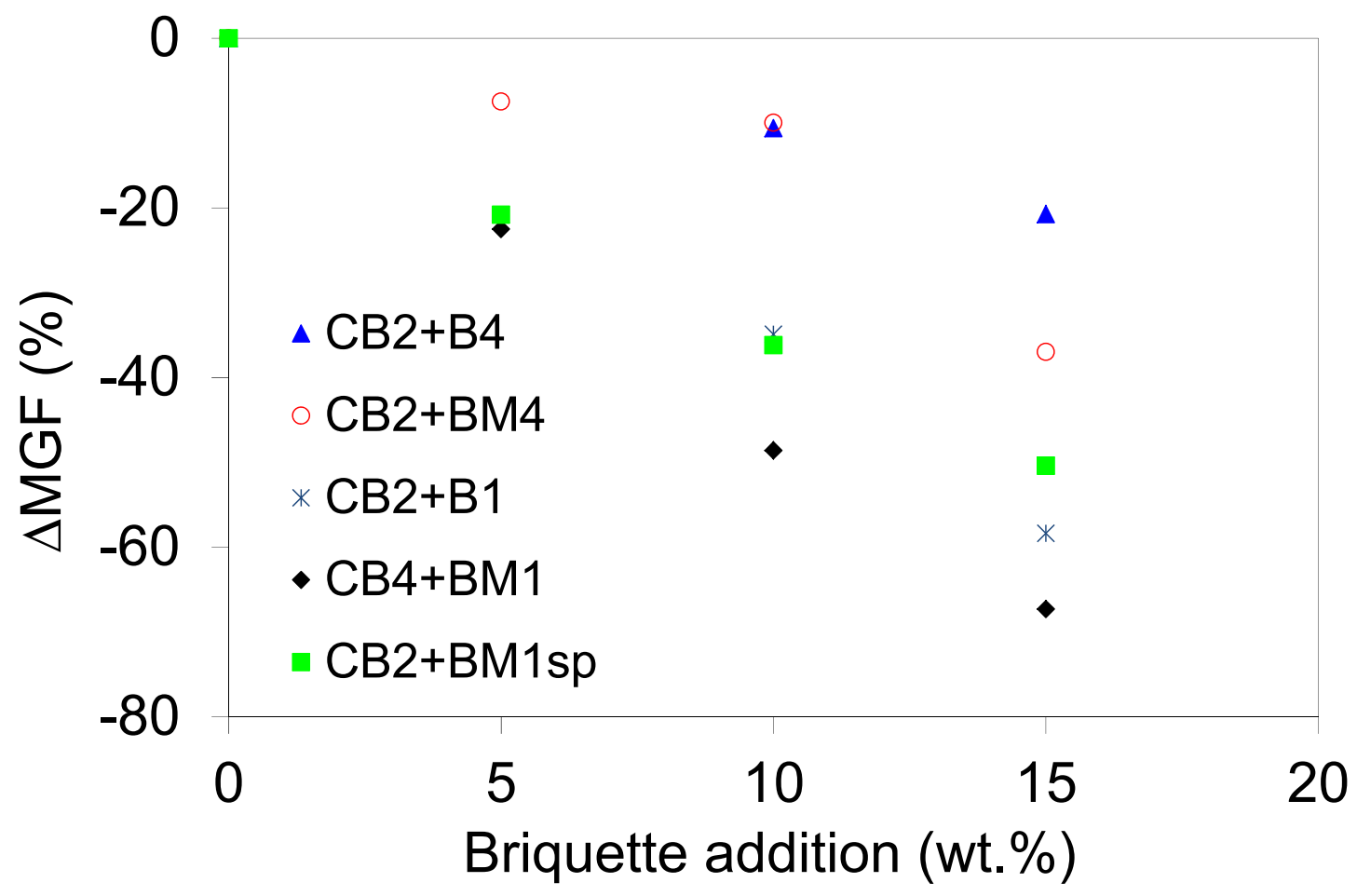

Figure 3. Influence of briquette addition on the maximum Gieseler fluidity of coal blends. 

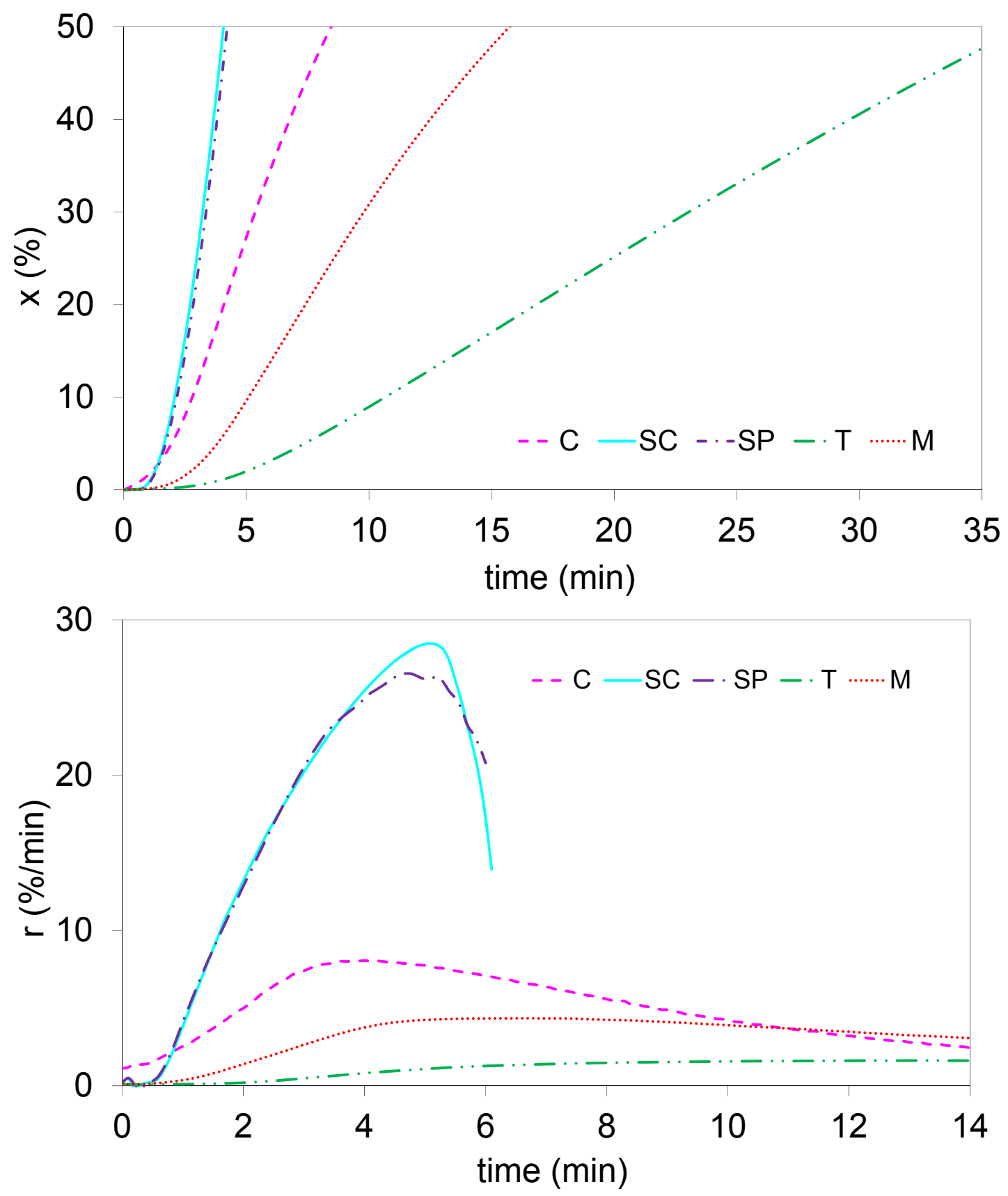

Figure 4. Variation of conversion (x) and reactivity (r) with gasification time. 

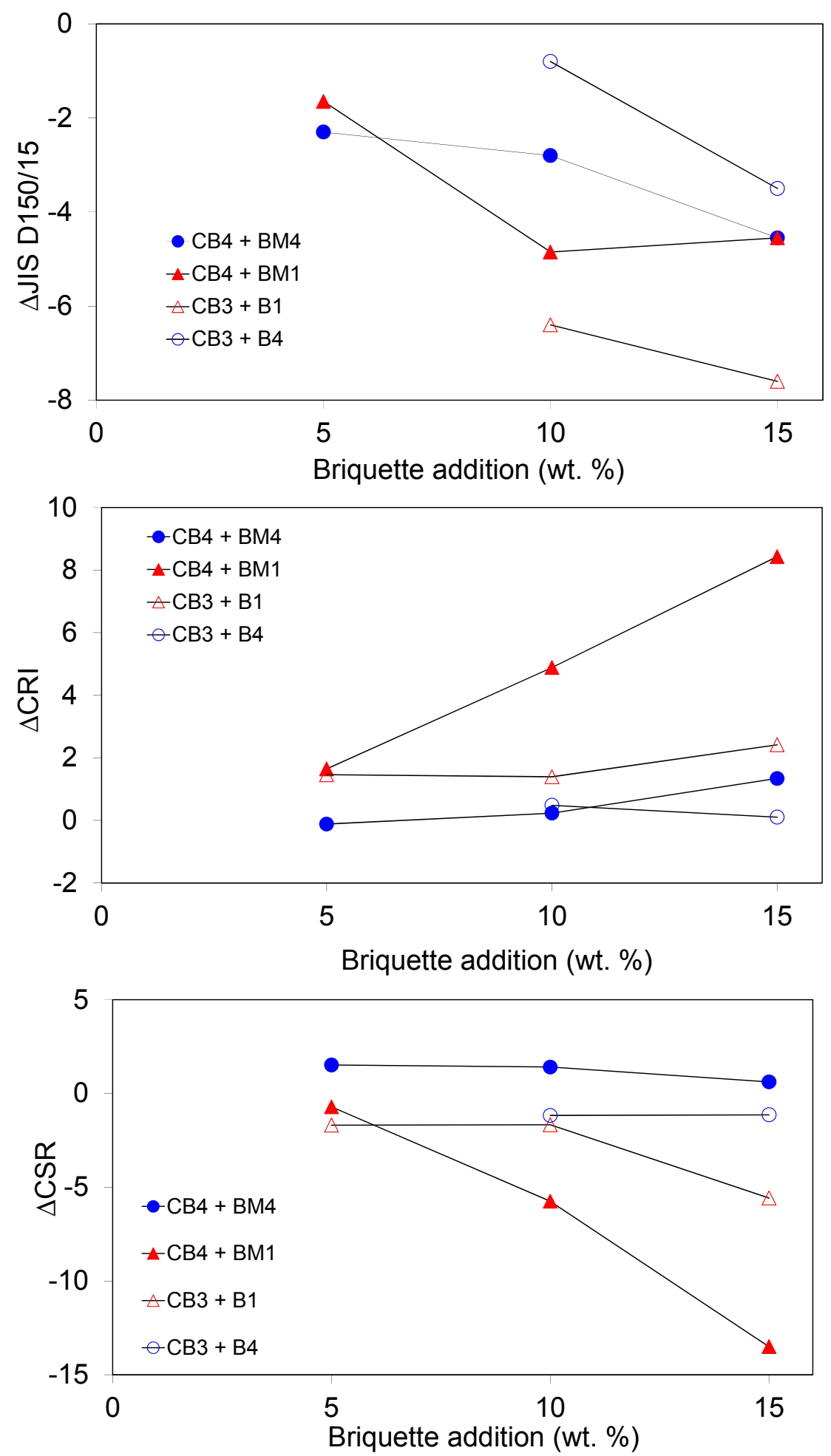

Figure 5. Variation of coke quality with briquette addition with sawdust (B1 and BM1) and without it (B4 and BM4) and using two binders coal tar (B1 and B4) and coal tar sludge (BM1 and BM4)). 

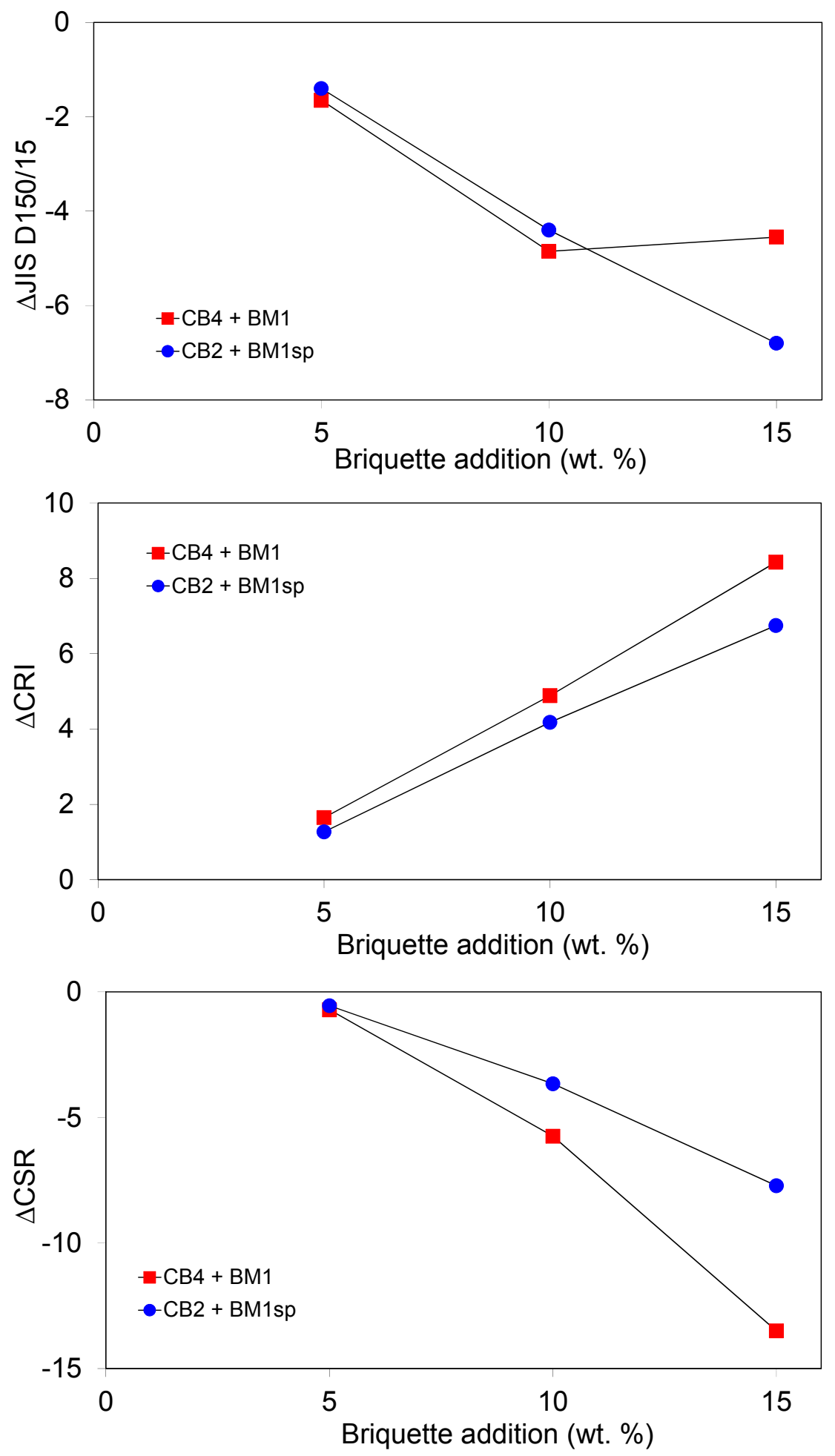

Figure 6. Variation of coke quality with briquette addition containing chestnut sawdust (BM1) and pine sawdust $\left(\mathrm{BM} 1_{\mathrm{SP}}\right)$ 

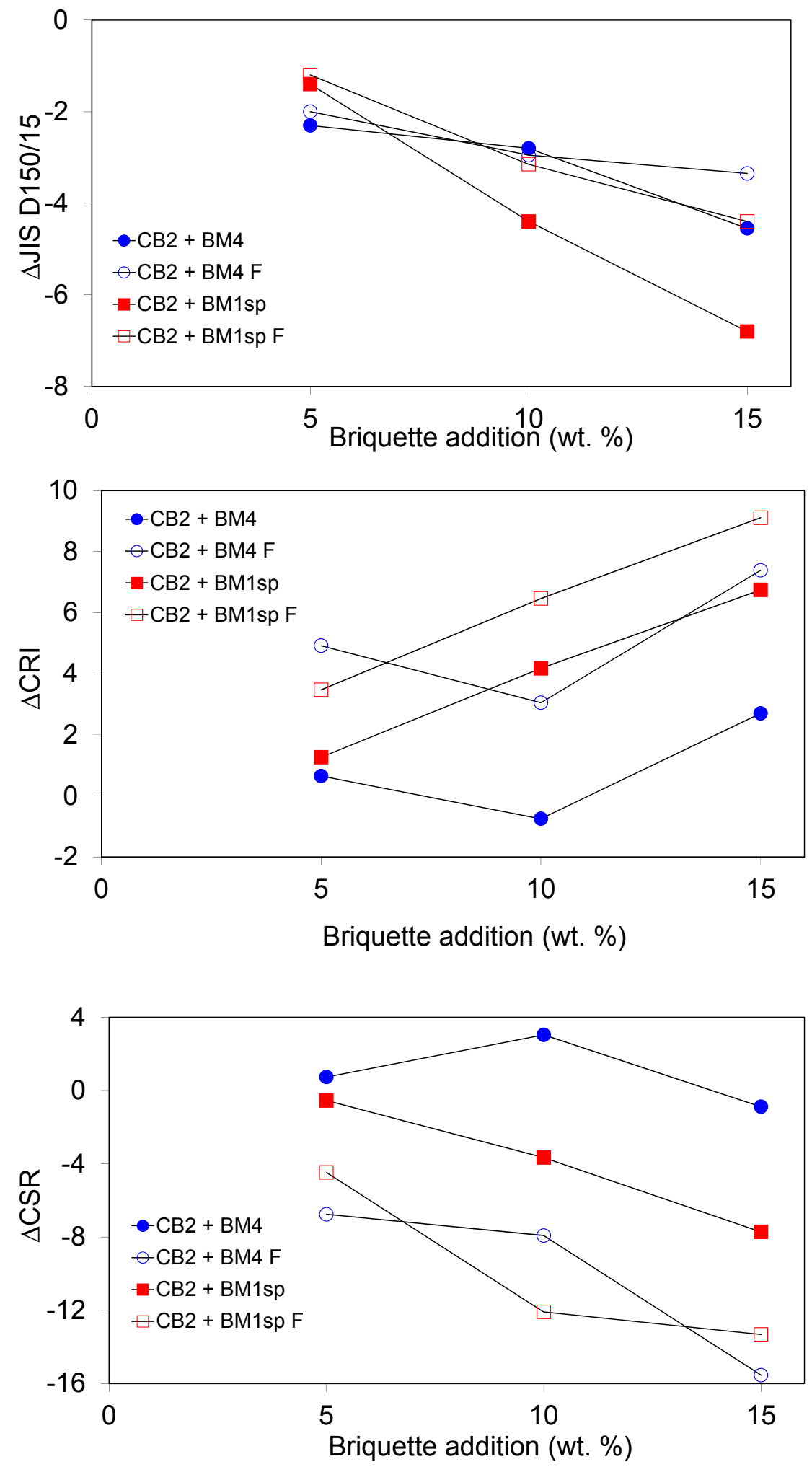

Figure 7. Variation of coke quality with briquette addition of two sizes (BM4 and BM4 $4_{F}$, and $\mathrm{BM} 1_{\mathrm{SP}}$ and $\left.\mathrm{BM} 1_{\mathrm{SP}-\mathrm{F}}\right)$. 